\title{
Total Antimony Determination in Galician Mussel Samples (Mytilus galloprovincialis) by Slurry Sampling - Graphite Furnace Atomic Absorption Spectrometry. Preliminary Results
}

\author{
M.D. Buján-Villar ${ }^{a}$, M.C. Barciela-Alonso ${ }^{a},{ }^{*}$ M. Aboal-Somoza ${ }^{b}$, and P. Bermejo-Barrera ${ }^{a}$ \\ ${ }^{a}$ University of Santiago de Compostela, Department of Analytical Chemistry, Nutrition and Bromatology, \\ Faculty of Chemistry, Avda. de las Ciencias, s/n, E-15782-Santiago de Compostela (La Coruña), Spain \\ ${ }^{b}$ University of Santiago de Compostela, Department of Analytical Chemistry, Nutrition and Bromatology. \\ Faculty of Sciences, Avda. Alfonso X El Sabio, s/n, E-27002-Lugo, Spain
}

\section{INTRODUCTION}

According to IUPAC recommendations, a trace element (like antimony) is any element having an average concentration of less than about 100 parts per million atoms (ppma) or less than $100 \mu \mathrm{g} \mathrm{g}^{-1}$ (1). Moreover, in the context of "trace" element analysis and due to the potential health and environmental hazards, some authors use terms such as microtrace, nanotrace, or picotrace levels of concentrations (2). Trace elements are well known to play an important role in the development and maintenance of life on our planet, yet some are highly toxic, whereas others are considered as essential but can become toxic at higher doses (3). These health-related facts justify the works devoted to the determination of trace elements in environmental, biological, and food samples.

Antimony is an element that is more toxic than its salts, its organic species are less toxic than the inorganic ones and, within the latter, $\mathrm{Sb}$ (III) is about 10 times more toxic than $\mathrm{Sb}(\mathrm{V})$. According to Nash et al. (4), there is evidence that antimony accumulates and, therefore, is of increasing concern with regard to the toxic concentrations and chemical forms in environmental systems.

Antimony is found in crustal rocks at a concentration of $0.2 \mathrm{~g}$ tonne $^{-1}(5)$. It is also present in the

\footnotetext{
*Corresponding autbor.
}

E-mail:m.aboal@usc.es

\begin{abstract}
A method is proposed for the determination of antimony in mussels by slurry samplingGFAAS, using $25.0 \mu \mathrm{g} \mathrm{mL} \mathrm{m}^{-1}$ each of palladium nitrate and magnesium nitrate as the chemical modifier. The best pyrolysis and atomization temperatures were found to be $1300^{\circ} \mathrm{C}$ and $1700{ }^{\circ} \mathrm{C}$, respectively. Due to the matrix effects observed, the standard additions method had to be applied.

The sample LOD and LOQ obtained was 16 and $56 \mu \mathrm{g} \mathrm{kg}^{-1}$, respectively. The mean analytical recovery of the method was 96.2\% and the method exhibits good precision. Real mussel samples collected in the estuary Ría de Arosa, in Galicia (Northwestern Spain) were analyzed.
\end{abstract}

open ocean (6) and in surface water of the North Atlantic ocean (7) at $0.2 \mu \mathrm{g} \mathrm{L}^{-1}$ and $1.7 \mathrm{nM}$, respectively. However, antimony levels in the aquatic environment can increase greatly due to natural events (such as rock weathering or soil erosion) and human activities, especially mining, smelting, and traffic emissions (8), as well as other industrial processes (9).

Consequently, public administrations and scientific institutions have issued recommended or permitted maximum levels of antimony in several media, but we have not found any literature concerning regulations pertaining to coastal or ocean waters. Some animal species, such as molluscs, have long been used as bioindicators of the quality and characteristics of the media where they live. In addition, the control and study of molluscs themselves can often have a particular economic interest. This is the case in our region, Galicia (located in Northwestern Spain), which is one of the most important producers of mussels in the world. The Galician coast has several estuaries (called "rías" in Spanish), where the Galician mussel (Mytilus galloprovincialis) is cultivated in floating nurseries by companies located in the Ría de Arosa (see Figure 1).

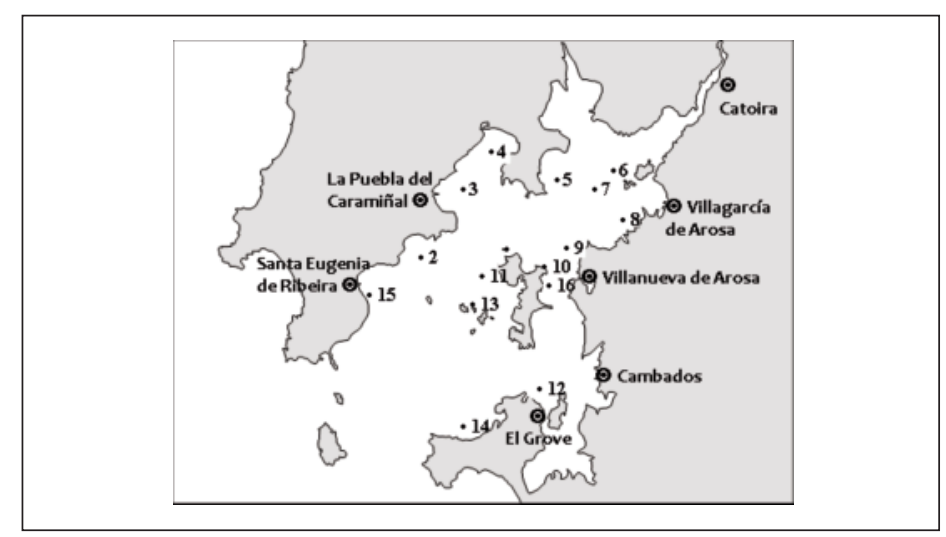

Fig. 1. Sampling sites in the Ría de Arosa estuary. 
The published literature available regarding the determination of antimony in mussels (which is the aim of this work) is rather limited. In most of these works, the sample is subjected to a nitric acid treatment both in open or closed vessels (10-13) or with different acid mixtures, such as nitric and perchloric acids (14), nitric and sulfuric acids $(15,16)$, or nitric, perchloric and sulfuric acids (10). The use of microwave energy is also reported to assist the acid digestion of the samples $(11,16)$. Other authors obtain cytosolic extracts (17-19) or just freeze-dry the samples (20), the latter method being a very simple sample pretreatment for use with neutron activation analysis (NAA).

In addition, inductively coupled plasma mass spectrometry (ICP-MS) is the analytical technique more frequently applied $(11,14,17-19,21)$, as well as atomic absorption $(12,13,15,16)$, inductively coupled plasma optical emission spectrometry (ICP-OES) (10), and neutron activation analysis (NAA) (20).

The work presented here is part of a wider research project with the aim to study the quality of the water of the Ría de Arosa by analyzing mollusks. For the determination of antimony in mussels, a graphite furnace atomic absorption spectrometric (GFAAS) method was developed using slurry sampling for injecting the sample into the atomizer. The goal was to verify whether slurry sampling is an alternative method to acid treatment of the sample as is usually proposed (16).

\section{EXPERIMENTAL}

\section{Instrumentation}

The antimony measurements were carried out at $217.6 \mathrm{~nm}$ using a PerkinElmer ${ }^{\circledR}$ Model 1100B atomic absorption spectrophotometer, equipped with a deuterium lamp background corrector, an $\mathrm{HGA}^{\circledR}-700$ graphite furnace, and an
AS-70 autosampler (PerkinElmer, Inc., Shelton, CT, USA). Pyrolytically coated graphite tubes with L'vov platform were used throughout (PerkinElmer, Inc.). The radiation source was an antimony hollow cathode lamp (Cathodeon, Ltd., Cambridge, UK). The instrumental operating conditions are listed in Table I

TABLE I

Instrumental Operating Conditions

\begin{tabular}{lr}
\hline Hollow cathode lamp & $\mathrm{Sb}$ \\
Wavelength & $217.6 \mathrm{~nm}$ \\
Lamp current & $10 \mathrm{~mA}$ \\
Slit width & $0.2 \mathrm{~nm}$ \\
Background correction & $\mathrm{D}_{2}$ lamp \\
Measurements & Integrated \\
absorbance
\end{tabular}

The temperature programs for the analysis of a sample slurry are listed in Table II. The chemical modifiers used (during the development of the method) were $0.5 \%(\mathrm{v} / \mathrm{v}) \mathrm{HNO}_{3}$ or a mixture of $\mathrm{Pd}\left(\mathrm{NO}_{3}\right)_{2}$ and $\mathrm{Mg}\left(\mathrm{NO}_{3}\right)_{2}$ at a concentration of $25.0 \mu \mathrm{g} \mathrm{mL}^{-1}$ (each nitrate). In the end, the chemical modifier proposed (see below) was the mixture of nitrates. The slurry analyzed also contained $0.1 \%(\mathrm{v} / \mathrm{v})$ Triton ${ }^{\circledR}$ $\mathrm{X}-100$ and, when using $\mathrm{Pd}\left(\mathrm{NO}_{3}\right)_{2}-$ $\mathrm{Mg}\left(\mathrm{NO}_{3}\right)_{2}, 0.8 \%$ (v/v) $\mathrm{H}_{2} \mathrm{O}_{2}$.

\section{Atomic Spectroscopy 1 Vol. 32(1), Jan./Feb. 2011}

\section{Standard Solutions and Reagents}

Antimony(V) stock standard solution (1003.1 $\left.\mu \mathrm{g} \mathrm{mL}^{-1}\right)$ was prepared by dissolving $0.2166 \mathrm{~g}$ of potassium hexahydroxyantimonate in ultrapure water $(99.99 \%$, p.a., Aldrich Chemical, Milwaukee, WI, USA) and diluting to $100 \mathrm{~mL}$ (working solutions were prepared from this solution). Argon N50, 99.999\% purity (SEO, Madrid, Spain), was used as sheathing gas for the atomizer. Also used were hydrogen peroxide 33\% (m/v) (Panreac Química S.A., Barcelona, Spain); nitric acid Hiperpur $^{\mathrm{TM}}$ (69.0\%) (Panreac Química S.A.); magnesium nitrate Suprapur ${ }^{\circledR}$ (Merck, Darmstadt, Germany), Triton ${ }^{\circledR} \mathrm{X}-100$, and polyethylene glycol mono p-(1,1,3,3-tetramethylbutyl) phenyl ether (Merck). Palladium nitrate solution (10 $\left.\mathrm{g} \mathrm{L}^{-1}\right)$ was prepared by dissolving palladium powder (99.999\%) (Aldrich Chemical) in 10\% (v/v) nitric acid. Ultrapure water, resistivity $18 \mathrm{M} \Omega$ $\mathrm{cm}$, was obtained with a Milli-Q ${ }^{\mathrm{TM}}$ water purification system (Millipore Corporation, Bedford, MA, USA).

\section{Samples}

The mussel samples were pulverized using a vibrating zircon mill, equipped with zircon cups $(15 \mathrm{~mL}$ in size) and zircon beads ( $7 \mathrm{~mm}$ diameter) (Retsch GmbH, Haan, Germany). An agitator (Vibromatic Selecta, Barcelona, Spain) and a magnetic stirrer (Agimatic, Selecta) were used in the slurry preparation.

TABLE II

Temperature Programs and Instrumental Operating Conditions Using $0.5 \% \mathrm{HNO}_{3}$ as Chemical Modifier

\begin{tabular}{llllc}
\hline Step & $\begin{array}{l}\text { Temp. } \\
\left({ }^{\circ} \mathrm{C}\right)\end{array}$ & $\begin{array}{c}\text { Ramp } \\
(\mathrm{s})\end{array}$ & $\begin{array}{c}\text { Hold } \\
(\mathrm{s})\end{array}$ & $\begin{array}{c}\text { Ar Flow } \\
\left(\mathrm{mL} \mathrm{min}^{-1}\right)\end{array}$ \\
\hline Dry 1 & 100 & 5 & 40 & 300 \\
Dry 2 & 140 & 5 & 30 & 300 \\
Pyrolysis 1 & 480 & 10 & 10 & 300 \\
Pyrolysis 2 & $1200 / 1300^{\mathrm{a}}$ & $10 / 7^{\mathrm{a}}$ & $14 / 40^{\mathrm{a}}$ & 300 \\
Atomization & $1900 / 1700^{\mathrm{a}}$ & 0 & 2 & 0 (read) \\
Clean & 2300 & 1 & 3 & 300 \\
\hline
\end{tabular}

${ }^{a}$ Temperatures and times for $\mathrm{Pd}\left(\mathrm{NO}_{3}\right)_{2}-\mathrm{Mg}\left(\mathrm{NO}_{3}\right)_{2}$ as chemical modifier. 


\section{Procedure for Sample Preparation and Analysis}

The proposed procedure is based on previous works devoted to the determination of elements (such as lead and arsenic) in mussels using slurry sampling $(22,23)$.

The mussel sample was first freeze-dried and then powdered in a $\mathrm{Zr}$ ball mill. Then, $0.25 \mathrm{~g}$ of the sample was accurately weighed into a polyethylene vial, where $5 \mathrm{~g}$ of $\mathrm{Zr}$ beads and $3 \mathrm{~mL}$ of ultrapure water were added. The vial was mechanically stirred for 45 minutes (making the diameter of the sample particles shorter than $5 \mu \mathrm{m}$ ) and, after stirring, the beads were separated using a ceramic funnel. The slurry was made up to $10 \mathrm{~mL}$ with ultrapure water in a volumetric flask. The slurry was kept in a refrigerator until measurement of the antimony concentration by graphite furnace atomic absorption spectrometry (GFAAS).

The test slurry had a volume of $1 \mathrm{~mL}$ and contained $500 \mu \mathrm{L}$ of the sample slurry, $0.6 \%(\mathrm{v} / \mathrm{v})$ of hydrogen peroxide, $0.1 \%(\mathrm{v} / \mathrm{v})$ of Triton $\mathrm{X}-100,25.0 \mu \mathrm{g} \mathrm{mL}-1$ of palladium nitrate and $25.0 \mu \mathrm{g} \mathrm{mL} \mathrm{m}^{-1}$ magnesium nitrate (the two latter act as chemical modifier). The test slurry was made up to $1 \mathrm{~mL}$ with ultrapure water and subjected to GFAAS. The standard additions method was applied for quantitation.

\section{Cleaning of Material}

To prevent contamination, all laboratory material was washed and kept for 48 hours in a 10\% (v/v) $\mathrm{HNO}_{3}$ solution, then it was carefully rinsed several times with ultrapure water and left to dry before use.

\section{RESULTS AND DISCUSSION}

\section{Temperature Programs}

Even when the organic matrix of a sample would make the use of a chemical modifier mandatory, investigation for selecting the best temperature for the pyrolysis and atomization steps was carried out with and without chemical modifier.

In a study by Cal-Prieto et al. (24), different chemical modifiers were used for antimony determination in soils and sediment slurries. In that work, seven substances were tested and $0.5 \% \mathrm{HNO}_{3}$ was selected as the chemical modifier. In addition, since a mixture of palladium/magnesium nitrates has been widely recommended as the chemical modifier (16), and we have also used it recently for antimony determination in acid-digested mussels, we decided to study its applicability for the present study.

A standard solution containing $30.0 \mu \mathrm{g} \mathrm{L}^{-1}$ of antimony was used to obtain the best pyrolysis and atomization temperatures without chemical modifier. Figure 2 shows the temperatures of 1100 and $2200{ }^{\circ} \mathrm{C}$ chosen for the pyrolysis and atomization steps, respectively. This selection was made on the basis of both the integrated absorbance values measured and the shape of the signals recorded.

To evaluate its effect as chemical modifier, nitric acid was added to a $30.0 \mu \mathrm{g} \mathrm{L}^{-1}$ antimony standard solution to give a concentration of $0.5 \%$ (v/v). We chose 1200 and $1700{ }^{\circ} \mathrm{C}$ for the pyrolysis and atomization steps, respectively (see Figure 2).

A standard solution (containing $8.0 \mu \mathrm{g} \mathrm{\textrm {L } ^ { - 1 }}$ of antimony, $25.0 \mu \mathrm{g} \mathrm{\textrm {mL } ^ { - 1 }}$ of palladium nitrate, and $25.0 \mu \mathrm{g} \mathrm{mL}^{-1}$ of magnesium nitrate) was prepared to check the mixture of palladium/ magnesium nitrates for its modifier capability. The concentration of antimony in this experiment is lower $\left(30.0 \mu \mathrm{g} \mathrm{L}^{-1}\right)$ than that used in the experiments described above because in this case a much higher absorbance signal was observed. It was found that 1000 and $2000{ }^{\circ} \mathrm{C}$ were the best temperatures for the pyrolysis and atomization steps, respectively (Figure 2 ).

Therefore, when analyzing a standard solution, nitric acid seems to be the most appropriate option, since it allows higher temperatures for the pyrolysis step and lower for the atomization step. In these three experiments, the background signals recorded were negligible.

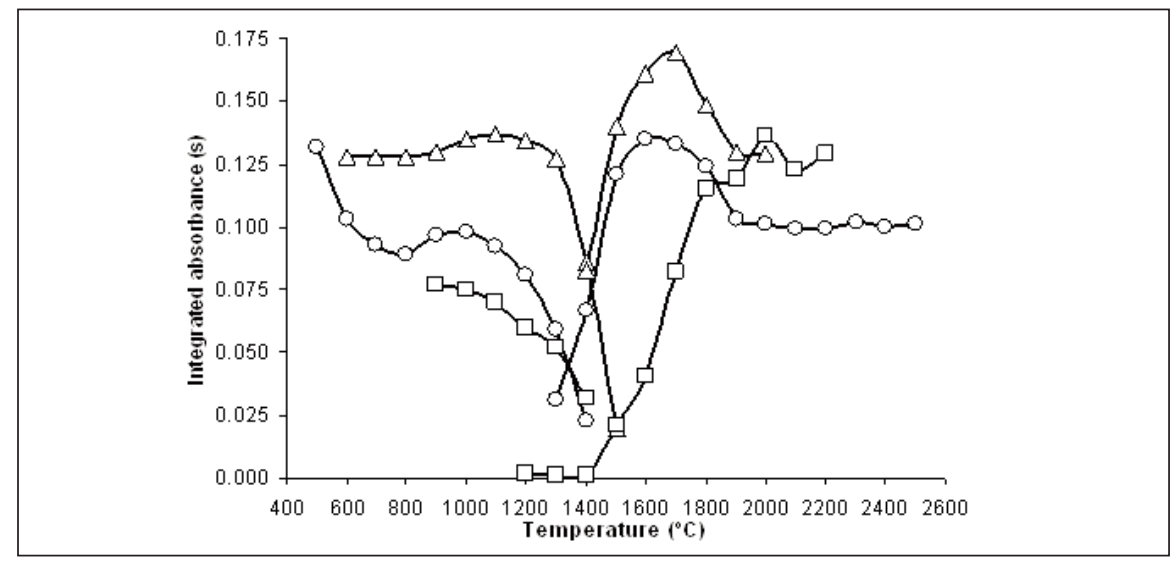

Fig. 2. Pyrolysis and atomization curves obtained for a standard solution, containing $30.0 \mu g \mathrm{~L}^{-1}$ of antimony $\left(8.0 \mu \mathrm{g} \mathrm{L} \mathrm{L}^{-1}\right.$ when using $\left.\mathrm{Pd}\left(\mathrm{NO}_{3}\right)_{2}-\mathrm{Mg}\left(\mathrm{NO}^{3}\right)_{2}\right)$. O-lines: Without chemical modifier; $\Delta$-lines: $0.5 \%(v / v) \mathrm{HNO}_{3}$; $\square$-lines: $25.0 \mu \mathrm{gL}^{-1}$ of $\mathrm{Pd}\left(\mathrm{NO}_{3}\right)_{2}$ and $25.0 \mu \mathrm{g} \mathrm{mL}-1$ of $\mathrm{Mg}\left(\mathrm{NO}_{3}\right)_{2}$. 


\section{Atomic Apectroscopy \\ $\bigcup$ Vol. 32(1), Jan./Feb. 2011}

The next series of experiments were devoted to finding the best pyrolysis and atomization temperatures for a mussel slurry. In Table III, which shows the composition of the solutions investigated, some aspects need emphasizing: Firstly, the amount of spike (i.e., antimony standard solution) was set depending on the amount of signal recorded in each case; secondly, when using the mixture of palladium and magnesium nitrates, hydrogen peroxide helped the oxidation of the organic matter; and thirdly, a little volume of Triton X-100 (namely, an aliquot to obtain a concentration of $0.1 \%$ $(\mathrm{v} / \mathrm{v})$ of Triton X-100 in the test slurry) was also added to stabilize the slurry as well as to make the injection easy. Figures $3 a, 3 b$, and $3 \mathrm{c}$ show the results achieved: (a) without chemical modifier, (b) with nitric acid, and (c) with the mixture of palladium and magnesium nitrates as the chemical modifier, respectively. For deciding on the best temperatures in each case, not only the absorbance values measured were taken into account, but also the shape of the peaks recorded. All of these steps led to the temperatures indicated in Table III. In view of these data, working without a chemical modifier was rejected, and further experiments were carried out to establish the ramp and hold times of the temperature programs for both chemical modifiers (i.e., nitric acid and the mixture of palladium and magnesium nitrates). The instrumental operating conditions about the method are listed in Table I and the temperature

\section{TABLE III}

Composition of $1.0 \mathrm{~mL}$ Sample Slurry Solution for Study and Selection of Pyrolysis and Atomization Temperatures

\begin{tabular}{llll}
\hline \multirow{2}{*}{ Substance } & \multicolumn{3}{c}{ Chemical Modifier } \\
\cline { 2 - 4 } & None & \multicolumn{1}{c}{$\mathrm{HNO}_{3}$} & $\begin{array}{l}\mathrm{Pd}\left(\mathrm{NO}_{3}\right)_{2}- \\
\mathrm{Mg}\left(\mathrm{NO}_{3}\right)_{2}\end{array}$ \\
\hline Sample Slurry & $500.0 \mu \mathrm{L}$ & $500.0 \mu \mathrm{L}$ & $500.0 \mu \mathrm{L}$ \\
Antimony Spike & $30 \mu \mathrm{g} \mathrm{L}^{-1}$ & $40 \mu \mathrm{g} \mathrm{L}^{-1}$ & $10 \mu \mathrm{g} \mathrm{L}^{-1}$ \\
$\mathrm{HNO}_{3}$ & -- & $0.5 \%(\mathrm{v} / \mathrm{v})$ & - \\
$\mathrm{Pd}_{\left(\mathrm{NO}_{3}\right)_{2}}$ & -- & - & $25.0 \mu \mathrm{gL} \mathrm{mL}^{-1}$ \\
$\mathrm{Mg}_{\left(\mathrm{NO}_{3}\right)_{2}}$ & - & - & $25.0 \mu \mathrm{mL}^{-1}$ \\
$\mathrm{H}_{2} \mathrm{O}_{2}$ & - & - & $0.8 \%(\mathrm{v} / \mathrm{v})$ \\
Triton X-100 & $0.1 \%(\mathrm{v} / \mathrm{v})$ & $0.1 \%(\mathrm{v} / \mathrm{v})$ & $0.1 \%(\mathrm{v} / \mathrm{v})$ \\
\hline
\end{tabular}

Temperatures Selected

\begin{tabular}{llll}
\hline Pyrolysis & $1200{ }^{\circ} \mathrm{C}$ & $1300{ }^{\circ} \mathrm{C}$ & $1300{ }^{\circ} \mathrm{C}$ \\
Atomization & $1700^{\circ} \mathrm{C}$ & $1700^{\circ} \mathrm{C}$ & $1700^{\circ} \mathrm{C}$
\end{tabular}

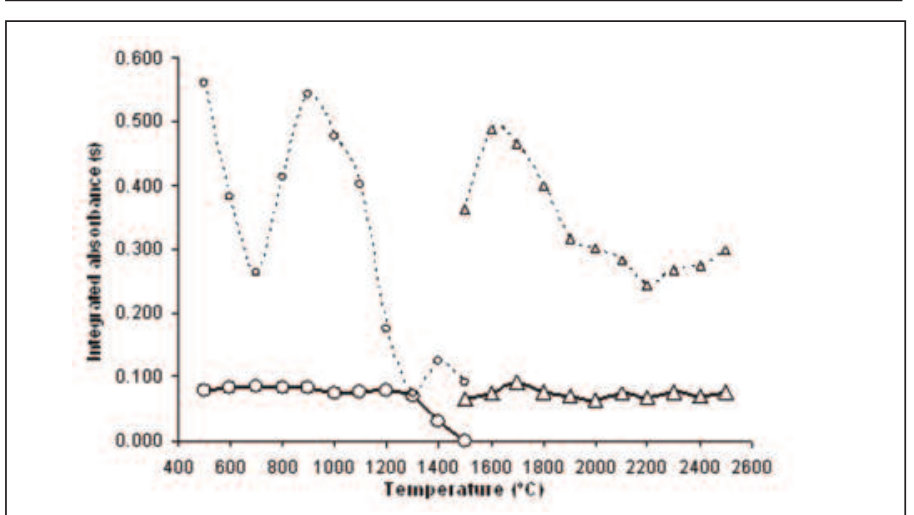

Fig. 3a. Pyrolysis and atomization curves obtained for a spiked sample slurry without chemical modifier. Spike: $30.0 \mu \mathrm{g} \mathrm{L}^{-1}$ of antimony, plus $0.1 \%(v / v)$ Triton $X-100$. Solid lines: Integrated absorbance; dotted lines: background absorption; O-lines: Pyrolysis; $\Delta$-lines: Atomization.

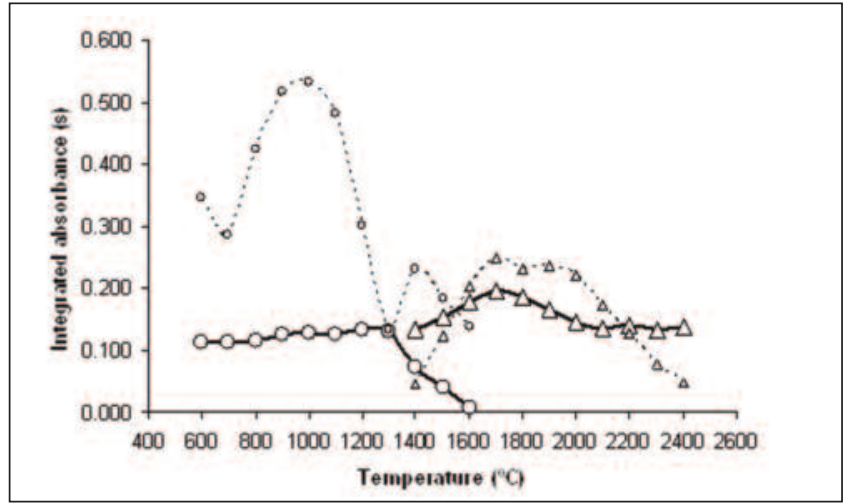

Fig. 3b. Pyrolysis and atomization curves obtained for a spiked sample slurry with $0.5 \%(v / v) \mathrm{HNO}_{3}$ as chemical modifier. Spike: $40.0 \mu \mathrm{g} L^{-1}$ of antimony, and also $0.1 \%$ $(v / v)$ of Triton $X-100$. Solid lines: Integrated absorbance; dotted lines: background absorption; O-lines: Pyrolysis; $\Delta$-lines: Atomization.

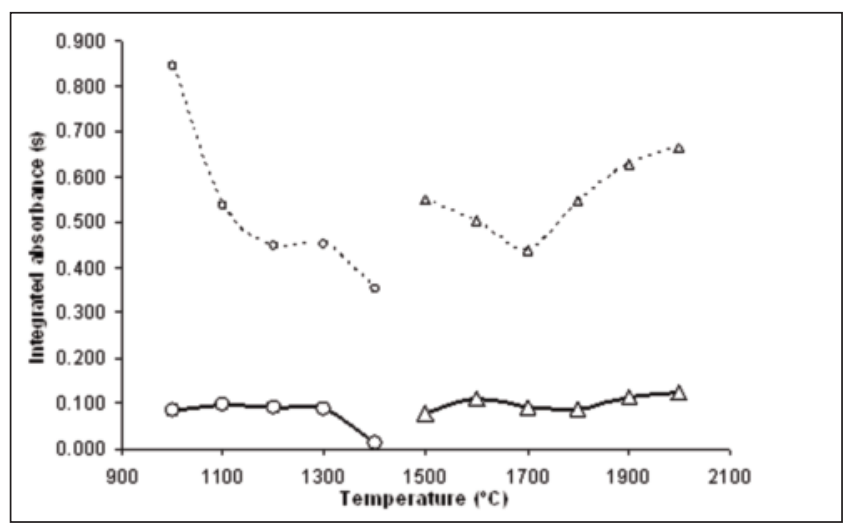

Fig. 3c. Pyrolysis and atomization curves obtained for a spiked sample slurry with $25.0 \mu \mathrm{g} \mathrm{mL} \mathrm{L}^{-1}$ of $\mathrm{Pd}\left(\mathrm{NO}_{3}\right)_{2}$ and $25.0 \mu \mathrm{g} \mathrm{mL} \mathrm{L}^{-1}$ of $\mathrm{Mg}\left(\mathrm{NO}_{3}\right)_{2}$ as chemical modifier. Spike: 10.0 $\mu g L^{-1}$ of antimony, and also $0.1 \%(v / v)$ of Triton $X-100$ and $0.8 \%(v / v) \mathrm{H}_{2} \mathrm{O}_{2}$ to belp oxidation of the organic matter. Solid lines: Integrated absorbance; dotted lines: background absorption; O-lines: Pyrolysis; $\Delta$-lines: Atomization. 
programs and other details in Table II (see page 35).

\section{Chemical Modifier and Hydrogen Peroxide}

In order to be able to discriminate between both chemical modifiers (nitric acid or palladium and magnesium nitrates), the effect of preconcentrating the sample in the graphite tube was evaluated for each modifier. For this purpose, two sample slurries were prepared each of them containing nitric acid or the palladium and magnesium nitrates mixture (as described in Table III, columns 3 and 4). Each solution was injected, dried, and pyrolyzed before the next injection. After the last injection, the complete temperature program was run. Best results for these series of measurements were obtained with two injections of $30 \mu \mathrm{L}$ each, for both chemical modifiers. This procedure of injection was applied in further studies.

For each chemical modifier, the most suitable concentration was also studied. For nitric acid, a series of 1-mL slurries containing $350 \mu \mathrm{L}$ of sample slurry, $40 \mu \mathrm{g} \mathrm{L}^{-1}$ of antimony spike, $0.1 \%(\mathrm{v} / \mathrm{v})$ of Triton $\mathrm{X}-100$, and nitric acid between 0.0 and $0.8 \%(\mathrm{v} / \mathrm{v})$ were subjected to GFAAS, and the results are shown in Figure 4. In view of these results, and also considering the shape of the peaks recorded, $0.5 \%$ (v/v) was considered the best concentration for nitric acid as the modifier, provided that lower concentrations produce higher values of background absorption.

Before carrying out a similar experiment for the mixture of palladium and magnesium nitrates, the amount of hydrogen peroxide to be added was revised. Thus, to a series of 1-mL slurries (consisting of $500 \mu \mathrm{L}$ of sample slurry, antimony spike of $10 \mu \mathrm{g} \mathrm{L}^{-1}$, Triton X-100 of $0.1 \%$ (v/v), $25.0 \mu \mathrm{g} \mathrm{mL}^{-1}$ of palladium nitrate and $25.0 \mu \mathrm{g} \mathrm{mL} \mathrm{magnesium}^{-1}$ magn nitrate, different amounts of hydrogen peroxide were added in order to obtain concentrations between 0 and $1.6 \%(\mathrm{v} / \mathrm{v})$. From the measurements recorded (when these slurries were subjected to GFAAS), it was concluded that hydrogen peroxide at a concentration of $0.6 \%(\mathrm{v} / \mathrm{v})$ was enough for obtaining suitable values of integrated absorbance and background absorption.

Finally, a similar experiment was carried out to study the concentration of the mixture of palladium and magnesium nitrates most suitable for the analysis of sample slurries: To a series of 1-mL slurries (containing $500 \mu \mathrm{L}$ of mussel sample slurry, $10 \mu \mathrm{g} \mathrm{L}^{-1}$ of antimony

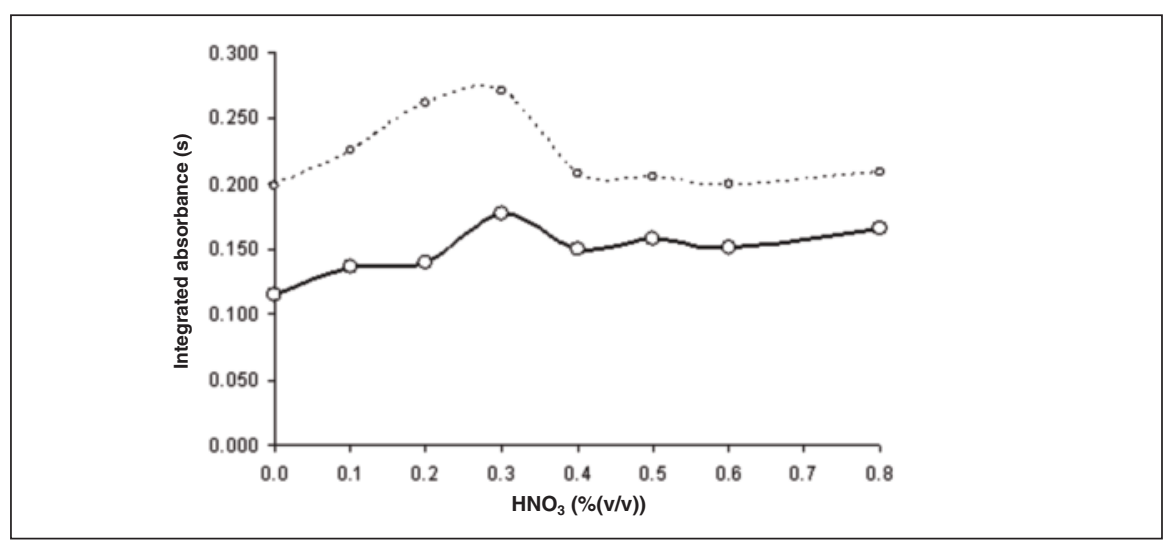

Fig. 4. Effect of the amount of $\mathrm{HNO}_{3}$ as chemical modifier on the integrated absorbance (solid line) and the background absorption (dotted line) of a spiked sample slurry.

spike, $0.1 \%(\mathrm{v} / \mathrm{v})$ of Triton $\mathrm{X}-100$, and $0.6 \%(\mathrm{v} / \mathrm{v})$ of $\mathrm{H}_{2} \mathrm{O}_{2}$, different amounts of palladium nitrate and magnesium nitrate solutions were added to give concentrations between 0 and $70 \mu \mathrm{g} \mathrm{mL} \mathrm{m}^{-1}$ of each nitrate. The slurries were subjected to GFAAS and the results obtained are shown in Figures 5a (integrated absorbance values) and 5b (background absorption values). Based on the same criteria as those pointed out in previous paragraphs, it was concluded that $25.0 \mu \mathrm{g} \mathrm{mL}^{-1}$ was the concentration of choice for both the palladium nitrate and magnesium nitrate.

\section{Analytical Figures of Merit}

Aqueous calibration and the standard additions methods were compared for both modifiers (nitric acid and the palladium and magnesium nitrates mixture). For this purpose, two series of $1 \mathrm{~mL}$ standard solutions and $1 \mathrm{~mL}$ slurries were prepared, one for each chemical modifier (one series containing $0.5 \%(\mathrm{v} / \mathrm{v})$ nitric acid and the other series containing $25.0 \mu \mathrm{g} \mathrm{mL} \mathrm{mL}^{-1}$ each of palladium nitrate and magnesium nitrate. In addition, $0.1 \%(\mathrm{v} / \mathrm{v})$ of Triton X-100 and $0.6 \%$ (v/v) of hydrogen peroxide were used. The concentration of antimony in the standard solutions and in the slurries ranged from 0 to $6.0-7.0 \mu \mathrm{g} \mathrm{L}^{-1}$, which is lower than the level used for the studies described in this work $\left(8.0,30.0\right.$ or $\left.40.0 \mu \mathrm{g} \mathrm{L}^{-1}\right)$, but indeed they are closer to the antimony levels expected to be found in the samples.

Table IV includes the equations of the regression lines calculated (by least squares method) for the aqueous calibration and standard addition graphs resulting from this study. For each chemical modifier, the slopes of the regression lines for both calibrations were statistically compared at a significance level of $\alpha=0.05$, which revealed significant differences between the slopes compared and for both of 


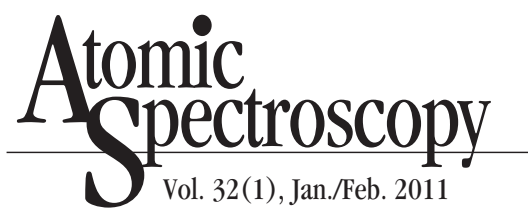

the chemical modifiers. This is due to the presence of matrix effects when using either nitric acid or the mixture of palladium and magnesium nitrates, thus making it mandatory to apply the standard additions method if quantitative results are to be achieved.

When the slopes calculated for the standard additions method for both modifiers were statistically compared at a significance level of $\alpha=0.05$, significant differences between both slopes were observed too. Moreover, in view of the values of both slopes (see Table IV: $7.400^{\bullet} 10^{-3} \mathrm{~L} \mathrm{\mu g}^{-1}$ and $1.081 \cdot 10^{-2} \mathrm{~L} \mathrm{\mu g}^{-1}$ ) it can be concluded that when the mixture of palladium and magnesium nitrates is used as the chemical modifier, the sensitivity of the analysis is enhanced 1.5 times. Thus, since nitric acid also reduces the lifetime of the graphite tubes, we decided to eliminate it for use as a chemical modifier.

Finally, the response is rectilinear at least up to $10 \mu \mathrm{g} \mathrm{L}^{-1}$ of antimony.

The sensitivity of the method (i.e., the slope of the calibration

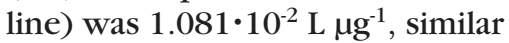
to the $1.27 \cdot 10^{-2} \mathrm{~L} \mathrm{\mu g}^{-1}$ achieved and reported for the quantification of antimony in digested mussel samples (16). Moreover, the sensitivity was also estimated by means of the limits of detection (LOD), the limits of quantification (LOQ), and the characteristic mass $\left(\mathrm{m}_{0}\right)$. The LOD and LOQ were calculated as $3 \mathrm{~s} / \mathrm{b}$ and $10 \mathrm{~s} / \mathrm{b}$, respectively (" $\mathrm{s}$ " is the standard deviation of the measurement of the blank and " $b$ " is the slope of the standard additions line) (25). The LOD and LOQ values for the test slurry were, respectively, 0.2 and $0.7 \mu \mathrm{g} \mathrm{L}^{-1}$, and for the mussel sample they were 16 and $56 \mu \mathrm{g} \mathrm{kg}^{-1}$, respectively.

The $\mathrm{m}_{0}$ was calculated according to the IUPAC definition (26) at different levels within the linear range of concentrations, and $29.2 \pm 0.9 \mathrm{pg}$ was the mean characteristic mass within that range.
The precision was studied from two points of view: (a) The repeatability (within-run precision) of the injection obtained from 10 replicate analyses of a single sample during the same run was 3.8\% (expressed as RSD). (b) The repeatability of the whole procedure was also studied by measuring five different slurries of the same sample. The within-batch precision (RSD) obtained was $6.5 \%$, which is also suitable given the complexity of the procedure.

Since a reference material for mussel with a certified antimony concentration was not available to us, the accuracy of the method developed was estimated by means of analytical recovery. Therefore, a series of slurries were prepared (as described above) containing an antimony spike to give added con-

\section{TABLE IV \\ Equations Calculated for External Standard Calibration and for Standard Additions Calibration when Using Nitric Acid or Pd-Mg Nitrates as Chemical Modifiers}

\begin{tabular}{lcc}
\hline \multicolumn{1}{c}{ Chemical Modifier } & \multicolumn{2}{c}{ Type of Calibration } \\
& \multicolumn{1}{c}{ External Standard } & Standard Additions \\
\hline $\mathrm{HNO}_{3}$ & $\mathrm{~A}^{\mathrm{a}}=4.571 \cdot 10^{-4}+1.533 \cdot 10^{-2} \mathrm{C}^{\mathrm{a}}$ & $\mathrm{A}^{\mathrm{a}}=6.300 \cdot 10^{-3}+7.400 \cdot 10^{-3} \mathrm{C}^{\mathrm{a}}$ \\
$\mathrm{Pd}\left(\mathrm{NO}_{3}\right)_{2}-\mathrm{Mg}\left(\mathrm{NO}_{3}\right)_{2}$ & $\mathrm{~A}^{\mathrm{a}}=2.292 \cdot 10^{-3}+6.356 \cdot 10^{-3} \mathrm{C}^{\mathrm{a}}$ & $\mathrm{A}^{\mathrm{a}}=1.715 \cdot 10^{-2}+1.081 \cdot 10^{-2} \mathrm{C}^{\mathrm{a}}$ \\
\hline
\end{tabular}

${ }^{\mathrm{a}} \mathrm{A}$ and $\mathrm{C}$ stand for integrated absorbance and antimony concentration (in $\mu \mathrm{g} \mathrm{L}^{-1}$ ), respectively.

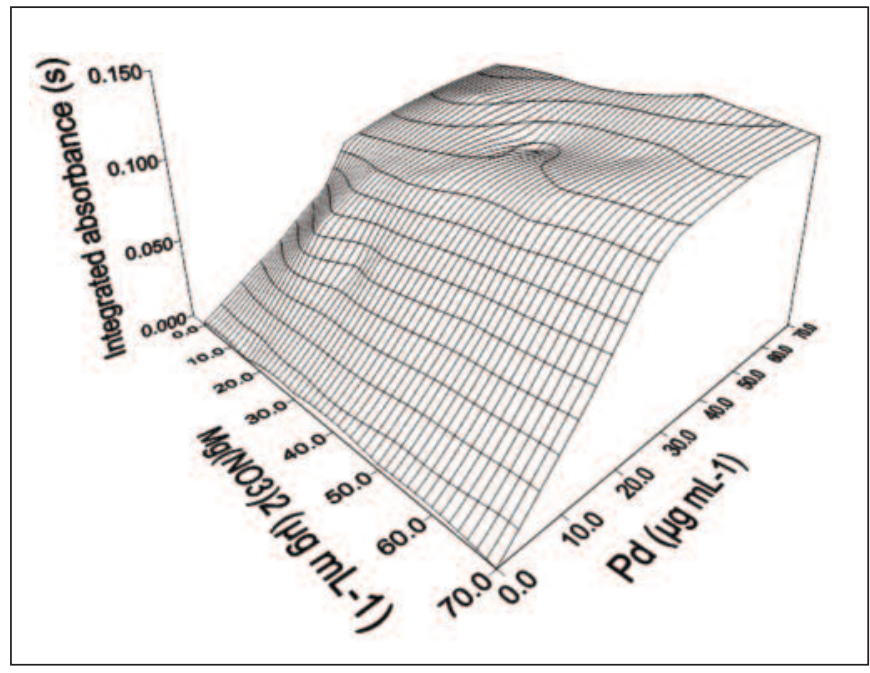

Fig. 5a. Effect of the amounts of $\mathrm{Pd}\left(\mathrm{NO}_{3}\right)_{2}$ and $\mathrm{Mg}\left(\mathrm{NO}_{3}\right)_{2}$ on the integrated absorbance of spiked sample slurries.

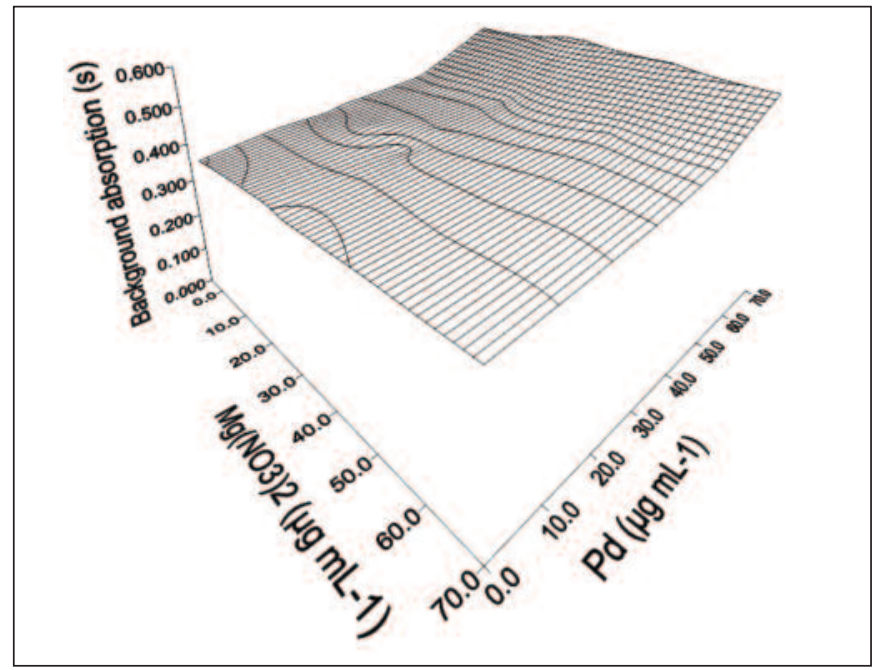

Fig. 5b. Effect of the amounts of $\mathrm{Pd}\left(\mathrm{NO}_{3}\right)_{2}$ and $\mathrm{Mg}\left(\mathrm{NO}_{3}\right)_{2}$ on the background absorption of spiked sample slurries. 
centrations between $3.0 \mu \mathrm{g} \mathrm{L}^{-1}$ and $10.0 \mu \mathrm{g} \mathrm{L}^{-1}$. The mean analytical recovery, calculated within the linear range of concentrations, was $96.2 \pm 3.2 \%$.

\section{Application to Real Samples}

Mussel samples were collected from 16 sampling points in the Ria de Arosa estuary (see Figure 1). Two slurries were prepared with each sample and subjected to the analytical procedure developed. Antimony was not detected in any of the samples analyzed, which means that the concentration of the analyte in those samples was lower than $16 \mu \mathrm{g} \mathrm{kg}^{-1}$.

\section{CONCLUSION}

Even though antimony could not be detected in any of the real mussel samples analyzed, this preliminary work shows that the slurry sampling technique can be applied to antimony determination in mussel samples. Probably, the analyte can be detected and quantified if preconcentration procedures are used.

However, the method developed exhibits aceptable sensitivity

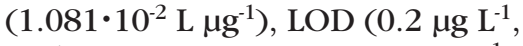
in the test slurry), LOQ $\left(0.7 \mu \mathrm{g} \mathrm{L}^{-1}\right.$, in the test slurry), characteristic mass $(29.2 \pm 0.9 \mathrm{pg}$, mean value within the linear range of concentrations) and also shows a good precision of the measurements. In addition, the mean analytical recovery achieved (96.2 $\pm 3.2 \%)$ verifies the accuracy of the method. These analytical figures of merit as well as the advantages of slurry sampling (no acid digestion, environmentally friendly, speed of analysis) make the method developed - at least at this preliminary stage - an interesting choice for antimony determination in mussel samples.

Received September 24, 2010.

\section{ACKNOWLEDGMENTS}

This research was finnantially supported by the Spanish Ministry of Science and Technology (project code CYSK5NPG).

\section{REFERENCES}

1. IUPAC, IUPAC Compendium of Chemical Terminology, Electronic version,

http://goldbook.iupac.org/T06421. html (accessed on 17th September 2010).

2. J.F. Escanero Marcen in: J.A. Cocho de Juan, J.F. Escanero Marcen and J.M. González de Buitrago (Ed.), Elementos Traza: Aspectos Bioquímicos, Analíticos y Clínicos, Sociedad Española de Bioquímica Clínica y Patología Molecular (SEQC), Barcelona, Spain, pg. 12 (1998).

3. D.M. Templeton, F. Ariese, R. Cornelis, L.-G. Danielsson, H. Muntau, H.P. Van Leeuwen, and R. Łobinski, Pure Appl. Chem. 72, 1453 (2000).

4. M.J. Nash, J.E. Maskall, and S.J. Hill, J. Environ. Monit. 2, 97 (2000).

5. N.N. Greenwood and A. Earnshaw, Chemistry of the Elements 2nd Ed., Butterworth-Heinemann, Oxford, UK, pg. 548 (1997).

6. R.E. Sturgeon, S.N. Willie, and S.S. Berman, Anal. Chem. 57, 6 (1985).

7. K. Kremling in: K. Grasshoff, K. Kremling, and M. Ehrhardt, Methods of Seawater Analysis, 3rd Ed., Wiley-VCH, Weinheim, Germany, pg. 254 (1999).

8. M. Patriarca, A. Menditto, B. Rossi, T.D.B. Lyon, and G.S. Fell, Microchem. J. 67, 351 (2000).

9. P. Smichowski, M.B. de la Calle Guntiñas, and C. Cámara, Fresenius' J. Anal. Chem. 348, 380 (1994).

10. P. Schramel and L.-Q. Xu, Fresenius' J. Anal. Chem. 340, 41 (1991).

11. S. Zimmermann, F. Alt, J. Messerschmidt, A. von Bohlen, H. Taraschewski, and B. Sures, Environ. Toxicol. Chem. 21, 2713 (2002).
12. Z.-Q. Fang, R.Y.H. Cheng, and M.H. Wong, J. Environ. Sci. 15, 9 (2003).

13. Z.-Q. Fang, Toxicol. Environ. Chem. 88, 45 (2006).

14. K. Benkhedda, H. Goenaga Infante, E. Ivanova, and F.C. Adams, J. Anal. At. Spectrom. 15, 1349 (2000).

15. K. Ikebe, R. Tanaka, and M. Ikeda, J. Food Hyg. Soc. Japan 24, 480 (1983).

16. B. Curros-Gontad, M.C. BarcielaAlonso, M.D. Buján-Villar, E.M. Peña-Vázquez, and P. Bermejo-Barrera, At. Spectrosc. 28, 144 (2007).

17. C.N. Ferrarello, $M^{a}$.R. Fernández de la Campa, C. Sariego Muñiz, and A. Sanz-Medel, Analyst 125, 2223 (2000).

18. C.N. Ferrarello, M. Montes Bayón, M.R. Fernández de la Campa, and A. Sanz-Medel, J. Anal. At. Spectrom. 15, 1558 (2000).

19. C.N. Ferrarello, M.R. Fernández de la Campa, and A. Sanz-Medel, Anal. Bioanal. Chem. 373, 412 (2002).

20. S.R. Guevara, D. Bubach, P. Vigliano, G. Lippolt, and M. Arribére, Biol. Trace Element Res. 102, 245 (2004).

21. F. Gagné, C. Blaise, I. Aoyama, R. Luo, C. Gagnon, Y. Couillard, P. Campbell, and M. Salazar, Environ. Toxicol. 17, 149 (2002).

22. P. Bermejo-Barrera, M. AboalSomoza, R.M. Soto-Ferreiro, and M.R. Domínguez-González, Analyst 118, 665 (1993).

23. P. Bermejo-Barrera, M.J. LorenzoAlonso, M. Aboal-Somoza, and A. Bermejo-Barrera, Mikrochim. Acta 117, 49 (1994).

24. M.J. Cal-Prieto, A. Carlosena, J.M. Andrade, S. Muniategui, P. LópezMahía, and D. Prada, At. Spectrosc. 21, 93 (2000).

25. Ll. A. Currie, Pure Appl. Chem. 67, 1699 (1995).

26. T. A. M. Ure, L. R. P. Butler, B. V. L'vov, I. Rubeska, and R. E. Sturgeon, Pure Appl. Chem. 64, 253 (1992). 